BEATA LORENS

Uniwersytet Rzeszowski

\title{
BAZYLIANIE JAKO WŁAŚCICIELE DÓBR KLASZTORNYCH W DRUGIEJ POŁOWIE XVIII WIEKU
}

Zarys treści: Bazylianie z racji posiadania dóbr ziemskich, nadanych im na mocy fundacji, sprawowali zarząd nad folwarkami klasztornymi. W nadzorowaniu poddanych i organizacji pracy kierowali się wytycznymi sformułowanymi w instruktarzach ekonomicznych. Przykładem tego typu dokumentu była instrukcja dla prokuratora, czyli zakonnika zarządzajacego gospodarstwem folwarcznym monasteru w Werchracie w województwie bełskim, pochodzaca z 1768 r. Sformułowano w niej zasady postępowania prokuratora wobec właścicieli sasiednich gruntów, czeladzi i poddanych klasztornych, opieki nad budynkami folwarcznymi i inwentarzem żywym oraz troską o zebranie i przechowywanie zbiorów.

The content outline: The Basilian monks, by reason of their ownership of landed estates conferred to them by charters, managed monastic manors. In supervising their subjects and in organising work they followed the guidelines set out in economic instructions, such as an instruction for the procurator, i.e. the Basilian father stewarding a manor at the village of Werchrata in the Bełz Voivodeship, formulated in 1768. The instruction contains rules of the procurator's conduct towards the owners of neighbouring estates, the domestics, servants and subjects of the monastery, his care for manorial buildings and livestock, for harvest and crops.

Słowa kluczowe: bazylianie, monaster, instrukcja ekonomiczna, folwark, gospodarka, poddaństwo

Keywords: Basilian Fathers, monastery, economic instruction, manor, economy management, serfdom 


\section{Wprowadzenie}

Zagadnienie gospodarowania $\mathrm{w}$ dobrach ziemskich należacych do klasztorów cieszy się w ostatnich latach coraz większą popularnościa. Znaczenie działalności gospodarczej dla funkcjonowania klasztorów, a z drugiej strony wkład zakonników w rozwój gospodarczy ziem polskich w średniowieczu i okresie nowożytnym były przedmiotem rozważań podejmowanych podczas konferencji naukowych ${ }^{1}$. Problematyka gospodarowania $\mathrm{w}$ dobrach klasztornych występowała $\mathrm{w}$ odniesieniu do zgromadzeń zakonnych oraz poszczególnych klasztorów. Spośród zakonów łacińskich temat funkcjonowania gospodarczego majątków klasztornych podejmowano w stosunku do cystersów, dominikanów, paulinów, franciszkanów, bernardynów czy jezuitów². Gospodarcze zaplecze monastycyzmu wschodniego, którego reprezentantami byli bazylianie (Ordo Sancti Basilii Magni), znacznie rzadziej znajdowało swoje omówienie w literaturze przedmiotu. Kwestie gospodarcze poruszano przy okazji charakterystyki poszczególnych domów zakonnych, skupiając się przede wszystkim na nakreśleniu kondycji finansowej w świetle opisów inwentarzowych. Szersze spojrzenie na stan majątkowy monasterów bazyliańskich w drugiej połowie XVIII w. znalazło się w monografii bazyliańskiej prowincji Opieki NMP, obejmującej klasztory zlokalizowane w południowo-wschodniej Rzeczypospolitej ${ }^{3}$ oraz $\mathrm{w}$ artykułach naukowych poświęconych kasacie monasterów ${ }^{4}$.

${ }^{1}$ Klasztor $w$ gospodarce średniowiecznej i nowożytnej, red. M. Derwich, Wrocław 2013 (Opera ad historiam monasticam spectantia, I, 9).

${ }^{2}$ M. Miławicki, Zaplecze gospodarcze klasztorów dominikańskich diecezji kamienieckiej w świetle akt wizytacji z 1823 roku, w: Dominikanie na ziemiach polskich w epoce nowożytnej, red. A. Markiewicz, M. Miławicki, Kraków 2009 (Studia i Źródła Dominikańskiego Instytutu Historycznego w Krakowie, 5), s. 485-517 (tamże bibliografia dotycząca gospodarowania w dobrach należących do dominikanów, s. 487-488, przyp. 8); A. Pobóg-Lenartowicz, Uposażenie klasztoru i klasztorna gospodarka (do poczatku XVI w.), w: Cystersi w Rudach, red. F. Wolnik, Opole 2009 (Z Dziejów Kultury Chrześcijańskiej na Śląsku, 59), s. 79-91; T. Przybysz, Stosunki spoteczno-gospodarcze $w$ dobrach klasztoru cystersów $w$ Eeknie - Wagrowcu $w$ okresie gospodarki folwarczno-pańszczyźnianej (XVI-XVIII wiek), w: Studia i materiały do dziejów Patuk, t. 2: Osadnictwo $i$ architektura $w$ rejonie Łekna we wczesnym średniowieczu, red. A. M. Wyrwa, Poznań 1995, s. 445-543; M. Zdanek, Inwentarze dóbr i folwarków opactwa cystersów w Mogile z XVI-XVII wieku, w: Folwark, wieś, latyfundium. Gospodarstwo wiejskie $w$ Rzeczypospolitej $w$ XVI-XVIII wieku, red. J. Muszyńska, S. Kazusek, J. Pielas, Kielce 2009, s. 173-185.

${ }^{3}$ B. Lorens, Bazylianie prowincji koronnej w latach 1743-1780, Rzeszów 2014, s. $185-234$.

${ }^{4}$ Taż, Sytuacja gospodarcza monasterów bazyliańskich w Galicji u progu kasat józefinskich oraz losy ich majatku po kasacie. Zarys problemu, w: Klasztor w gospodarce 
Warto również zwrócić uwagę na opracowania poświęcone działalności gospodarczej bazylianek ${ }^{5}$.

Od czasów reformy bazylianów dokonanej przez unickiego metropolitę kijowskiego Jozafata Welamina Rutskiego w 1617 r. warunkiem założenia monasteru bazyliańskiego, tak jak i innych klasztorów rzymskokatolickich, było zagwarantowanie uposażenia pozwalającego utrzymać określoną liczbę zakonników, wymaganą prawem kanonicznym. Majątki ziemskie bazylianów, jedynych wówczas przedstawicieli życia zakonnego w Cerkwi unickiej, były częścią składową dóbr duchownych należących do tego obrządku katolickiego, obok uposażenia unickich biskupstw i parochii.

Celem niniejszego artykułu jest charakterystyka działalności gospodarczej bazylianów jako właścicieli dóbr ziemskich, stanowiących uposażenie monasterów położonych na terenie południowo-wschodniej Rzeczypospolitej, a więc należących w drugiej połowie XVIII w. do prowincji pw. Opieki NMP (koronnej). Temat podstaw materialnych egzystencji klasztorów bazyliańskich został przeze mnie podjęty przy okazji monograficznego opracowania dziejów bazyliańskiej prowincji koronnej, jednak obecnie chciałabym spojrzeć na zagadnienie z nieco innej perspektywy i ukazać zakonników jako zarządzajacych powierzoną im ziemia i ludźmi. Podstawą opracowania są informacje dotyczące kwestii gospodarczych zawarte przede wszystkim w zaleceniach powizytacyjnych oraz instruktarzach ekonomicznych. Te ostatnie, tak liczne jeśli chodzi o dobra szlacheckie ${ }^{6}$, okazały się być wyjątkowym zjawiskiem w dokumentacji wytworzonej przez bazylianów. Instrukcje wydawane przez

średniowiecznej i nowożytnej..., s. 623-641; I. Wodzianowska, Sytuacja gospodarcza klasztoru bazylianów w Zahorowie na Wotyniu u progu kasat oraz losy jego majatku $i$ zabudowań po kasacie w 1839 r., w: Klasztor $w$ gospodarce średniowiecznej $i$ nowożytnej..., s. 663-682; Ю. Стецик, Монастирські фбільварки Перелишльської епархії (кінець XVII-XVIII cm.), „Історія релігій в Україні” 1, 2008, s. 540-546.

${ }^{5}$ O. Duch, Jak mniszki gospodarowaty? Gospodarka $w$ prawostawnych $i$ unickich monasterach żeńskich eparchii lwowskiej i przemyskiej $w$ XVII-XVIII wieku, w: Folwark, wieś, latyfundium..., s. 187-196; О. Дух, Превелебні панни. Жіночі чернечі спільноти Львівської та Перемиишльської єпархій у ранньомодерний період, Львів 2017, s. 277-306; W. Łoś, Sytuacja gospodarcza klasztorów bazylianek na Wotyniu u progu kasat (koniec XVIII - poczatek XIX w.), w: Klasztor w gospodarce średniowiecznej i nowożytnej..., s. 611-621.

${ }^{6}$ Polskie instruktarze ekonomiczne $z$ końca XVII $i z$ XVIII wieku, t. 1-2, wyd. S. Pawlik, Kraków 1915-1929; Instrukcje gospodarcze dla dóbr magnackich i szlacheckich z XVII-XVIII wieku, t. 1, wyd. B. Baranowski i in., Wrocław 1958 (Źródła do Historii Kultury Materialnej); Instrukcje gospodarcze dla dóbr magnackich $i$ szlacheckich $z$ XVII-XVIII wieku, t. 2, wyd. B. Baranowski i in., Wrocław-Warszawa-Kraków 1963 (Źródła do Historii Kultury Materialnej). 
władze zakonne dla ojców i braci nadzorujących majątki klasztorne, obowiąujace $\mathrm{w}$ dłuższym czasie, a nie stanowiace jednorazowego polecenia ${ }^{7}$, zawierały wskazówki co do sposobów gospodarowania i traktowania ludności poddańczej. Z XVIII w. udało się odnaleźć zaledwie jedna taka wytyczna, spisana w $1768 \mathrm{r}$. dla monasteru w Werchracie i podległej mu rezydencji w Jamnicy, położonych w województwie bełskim ${ }^{8}$. $\mathrm{Z}$ racji wyjątkowości instrukcja została zamieszczona w aneksie. Źródłem bardzo rzadkim była również korespondencja w sprawach gospodarczych prowadzona między zakonnikami. Częściej spotkać można było księgi „gospodarskie”, zawierające informacje o charakterze statystycznym. Materiał egzemplifikacyjny i statystyczny zawarty w wymienionych powyżej aktach posłuży analizie opisywanych zjawisk i procesów.

\section{Sytuacja klasztorów bazyliańskich w południowo-wschodniej Rzeczypospolitej}

W chwili powstania bazyliańskiej prowincji koronnej w 1743 r. znalazło się w niej ponad 130 klasztorów, położonych w południowo-wschodnich województwach państwa polsko-litewskiego (ruskie, bełskie, lubelskie, podolskie, wołyńskie, kijowskie, bracławskie). Przeważały wśród nich placówki bardzo słabo uposażone, niepozwalające na utrzymanie wymaganej liczby zakonników w konwencie. Z tego względu w kolejnych dziesięcioleciach trwał proces likwidacji opustoszałych monasterów. W jego wyniku zredukowano 52 klasztory, czyli 39\% wszystkich funkcjonujących, a 20 placówek (15\%) straciło samodzielność, stając się rezydencjami podporządkowanymi większym ośrodkom? ${ }^{9}$

Specyfiką lokalizacji monasterów bazyliańskich, wynikająca z tradycji wschodniej, było ich sytuowanie z dala od centrów osadniczych. Dopiero w XVIII w., po przyjęciu unii z Kościołem łacińskim przez większość monasterów i postawieniu przed bazylianami również zadań edukacyjnych, częściej sytuowano monastery w miastach lub przenoszono zakonników do nowych klasztorów, np. z Mańkówki do Humania czy z Kalinówki do Szarogrodu, Wołświna i Horodyszcza do Krystynopola.

${ }^{7}$ Definicję instruktarza ekonomicznego sformułował Stefan Pawlik; zob. Polskie instruktarze ekonomiczne..., t. 1, s. VII-VIII.

${ }^{8}$ Центральний Державний Історичний Архів України м. Львів (dalej: ЦДІА), f. 684, op. 1, sp. 1186, Inwentarz monasteru w Werchracie z rezydencją w Jamnicy 1766-1775, k. 71-72.

${ }^{9}$ B. Lorens, Redukcja monasterów w prowincji koronnej Zakonu Ruskiego św. Bazylego Wielkiego w latach 1744-1780, „Hereditas Monasteriorum” 8, 2016, s. 99. 
Dotychczasowe siedziby były wówczas przekształcane w folwarki monasterskie. Majątki ziemskie klasztorów bazyliańskich w południowo-wschodniej Rzeczypospolitej wiązały się z ich fundacja, która bardzo często dokonywana była w okresie przynależności monasterów do wyznania prawosławnego w XV-XVI w. W wyniku wydarzeń wojennych zwiazanych z powstaniem Chmielnickiego, najazdami tatarskimi i wojna polsko-turecka w drugiej połowie XVII w. monastery pustoszały. Mnisi uciekali, aby schronić się przed wojskami. Stwarzało to okazję do zagrabiania dóbr klasztornych przez sąsiadów. Często w takich sytuacjach tracono dokumenty fundacyjne, co uniemożliwiało skuteczne dochodzenie praw przez mnichów w późniejszym czasie. Powstawała wówczas konieczność ponownej fundacji lub też powiększenia uposażenia monasteru, aby mógł on zapewnić utrzymanie dla wymaganej prawem liczby zakonników ${ }^{10}$. To bowiem kwestia utrzymania w monasterze odpowiedniej ilości profesów była czynnikiem determinującym wielkość uposażenia w ziemię czy kapitał. Początkowo w konstytucjach zreformowanego zakonu bazyliańskiego określono konieczność utrzymania konwentu złożonego z dziesięciu zakonników ${ }^{11}$. Synod prowincjalny Cerkwi unickiej w Zamościu w 1720 r. postawił wymóg zapewnienia utrzymania dla 12 profesów, a w 1744 r. papież Benedykt XIV w dekrecie Inter plures określił wymaganą liczbę zakonników w konwencie na 10, a przynajmniej $8^{12}$. W drugiej połowie XVIII w. roczne utrzymanie jednego zakonnika szacowano na $300 \mathrm{złp}$, zatem w przypadku ośmiu zakonników monaster powinien osiagać roczny dochód w wysokości $2400 \mathrm{złp}^{13}$.

10 Tamże, s. 72.

${ }^{11}$ Regulae Monasticae Ordinis Sancti Basilii M., w: M.M. Wojnar, De regimine Basilianorum Ruthenorum a metropolitas Josepho Velamin Rutskyj instauratorum, Romae 1949 (Analecta Ordinis Sancti Basilii Magni, II, I, 1), s. 214.

${ }^{12}$ Synod prowincialny Ruski $w$ Mieście Zamoyściu Roku 1720 odprawiony, a w R. 1724 za rozkazem S. K. de Propag. F. tacińskim ięzykiem w Rzymie z druku wydany, potym wkrótce z zalecenia J. W. J. X. Leona Kiszki metropolity całey Rusi na polski przez J. X. Polikarpa Filipowicza Z. S. Bazylego W. opata pińskiego na Leszczu przewiedziony, $w$ tymże Języku dopiero $z$ stow istnościq sposobem pisania tamtych lat Pisarza $i$ z krótkim od tegoż dla Spowiednikow Pamiętnikiem przedrukowany, Wilno 1785, s. 137; Documenta Pontificum Romanorum Historiam Ucrainae illustrantia (1075-1953), t. 2: 1700-1953, wybór A.G. Welykyj, Romae 1954 (Analecta OSBM, II, 3), nr 704, s. 98-99.

${ }^{13}$ ЦДІА, f. 684, op. 1, sp. 3075, Inwentarz monasteru w Krystynopolu 1766-1786, k. 17v; ANK, I Oddział na Wawelu, Archiwum Sanguszków, teka 529, plik 31, Fundacja monasteru w Humaniu, 1766 r., k. 14v-15; BJ, rkps 4502, Rękopis klasztorny XX. Bazylianów humańskich, k. 6v-7; Львівська Національна Наукова Бібліотека України імені Василя Стефраника. Відділ Рукописів (dalej: ЛННБ), f. 3, od. zb. 137, Księga dokumentów monasterów prowincji koronnej 1759-1776, k. 95-95v. 
$\mathrm{Na}$ materialne podstawy funkcjonowania monasterów składały się przeważnie następujące elementy: dochody związane z uposażeniem $\mathrm{w}$ ziemię, kapitały pieniężne oraz wpływy finansowe pochodzące z działalności duszpasterskiej. Głównym źródłem utrzymania klasztorów bazyliańskich pozostawało gospodarstwo monasterskie, zorganizowane w formie folwarków. Jego podstawą była grunty orne, łąki, ogrody oraz niekiedy lasy. Areał obszaru należącego do monasterów ulegał zmianom w XVII i XVIII w. Z jednej strony bazylianie podejmowali starania o zwiększenie i zabezpieczenie prawne posiadanych przez siebie dóbr ziemskich, z drugiej natomiast tracili je na rzecz właścicieli sąsiednich majątków czy potomków fundatorów. Folwarki monasterskie, podobnie jak np. plebańskie czy sołtysie, istniały w obrębie wsi królewskiej, szlacheckiej czy duchownej. W przeciwieństwie do folwarków pańskich produkujaccych na zbyt, folwarki monasterskie służyły wytwarzaniu żywności przeznaczonej dla zakonników i służby klasztornej ${ }^{14}$. Ewentualne nadwyżki mogły być sprzedawane, ale uzyskane w ten sposób środki materialne stanowiły raczej niezbyt znaczący wkład do kasy klasztornej, np. w monasterze w Poczajowie w latach 1746-1780 sprzedaż produktów rolnych i zwierząt przynosiła od 2,4 do $13,7 \%$ przychodu rocznego ${ }^{15}$.

\section{Bazyliańskie rządy w folwarkach w świetle instrukcji ekonomicznej}

Posiadanie dóbr ziemskich z ludnościa poddańczą wymagało od zakonników sprawnego zarządzania nimi. Władze zakonnej prowincji Opieki NMP w latach 1743-1780 kwestiom gospodarowania w majątkach monasterskich właściwie nie poświęcały uwagi. Tematy związane ze sposobami gospodarowania i odnoszenia się do poddanych nie pojawiły się również $\mathrm{w}$ listach okólnych pisanych przez protoihumenów (prowincjałów). Jedyną okazja do sformułowania wytycznych w zakresie zarządzania dobrami były wizytacje monasterów. W zaleceniach powizytacyjnych spotyka się wskazówki związane z wysokością obciążeń chłopskich czy kierunkami działalności gospodarczej oraz uwagi dotyczące reperacji budynków folwarcznych ${ }^{16}$. Te drobne wzmianki

${ }_{14}$ J. Rutkowski, Co to byty folwarki $w$ dawnej Polsce?, w: Wieś europejska późnego feudalizmu (XVI-XVIII w.), wybór J. Topolski, Warszawa 1986, s. 237, 240.

${ }_{15}$ B. Lorens, Bazylianie prowincji koronnej..., s. 223.

${ }_{16}$ ЦДІА, f. 201, op. 46, sp. 1917, Inventaria Monasteriorum Ord[inis] S[ancti] P[atri] Basilii M[agni] sub Titulo Protectionis B[eatae] V[irginae] Mariae ab Anno $1730^{\mathrm{mo}}$ ad Annum $1765^{\text {tum }}$ compacta, k. 226. Ten rękopis występował także pod 
każą domniemywać, że przywołana w aneksie instrukcja ekonomiczna (aneks II) była przez długi czas obowiąująca nie tylko w odniesieniu do monasteru w Werchracie, ale podobne założenia realizowano we wszystkich klasztorach bazyliańskich w prowincji koronnej. Instrukcję zapisano w dokumentach monasterskich pod datą 26 II (15 II według kalendarza juliańskiego) 1768 r., najpewniej w związku z wizytacja protoihumena (prowincjała). Nie udało się ustalić osoby, która była jej autorem. Ihumenem monasteru werchrackiego był wówczas o. Modest Śliwiński i być może to właśnie on zapisał obowiąujące zasady, chcąc je przedstawić do zaaprobowania zwierzchnikowi prowincji ${ }^{17}$. Z kolei osoba wizytująca mógł być sam protoihumen Jozafat Siedlecki ${ }^{18}$ lub wydelegowany przez niego wizytator, najpewniej ówczesny wikary prowincji i wizytator Innocenty Matkowski. Wiadomo, że w na początku sierpnia (23 VII według kalendarza juliańskiego) 1768 r. klasztor wizytował właśnie wikary prowincji Innocenty Matkowski ${ }^{19}$. Instrukcja poprzedzona została krótką informacją dotycząca wydzielania gruntu ornego dla poddanych osadzanych w majatkach bazyliańskich. Zawarto w niej wskazówki dotyczące postępowania względem chłopów, stąd również i tę część umieszczono w aneksie (aneks I).

Folwarki monasterskie zlokalizowane były najczęściej w bezpośrednim sassiedztwie klasztorów. Zabudowania folwarczne budowano w pobliżu cerkwi monasterskiej i budynku klasztornego, nieraz tak blisko, że kolidowało to z zachowaniem klauzury. Tylko niewielka część monasterów (ok. 10-15\%) dysponowała więcej niż jednym folwarkiem. Monaster w Ławrowie posiadał w 1763 r. pięć folwarków: przy samym monasterze w Ławrowie oraz w pobliskich wsiach: Nanczułka, Wysoczany, Mokrzany i Szaszarowicze ${ }^{20}$. Trzy folwarki miał monaster w Szczepło-

sygn. f. 201, op. 4, sp. 613; Інститут Рукопису Національної Бібліотеки України ім. В. І. Вернадського в Київі (dalej: ІРНБУ), f. I, nr 1104, Acta Monasterii Lubarensis Anno, 1769 r., k. 26v; ІРНБУ f. 231, nr 152, Rewizja cerkwi unickich i monasterów 1687-1829, k. 171.

${ }_{17}$ Modest Śliwiński był ihumenem (superiorem, przełożonym) monasteru w Werchracie od października 1767 do końca września 1768 r.; zob. ЛННБ, f. 3, od. zb. 361, Księga wydatków (1760-1775) i przybytków (1768-1775) bazyliańskiego monasteru w Werchracie, k. 24v, 29.

18 Prowincjał Jozafat Siedlecki wizytował monaster w Werchracie na początku czerwca 1764 r., a rezydencję w Jamnicy (Smolinie) we wrześniu 1765 r.; zob. ЦДІА, f. 201, op. 46, sp. 1917, k. 250, 267v.

${ }^{19}$ ЦДІА, f. 684 , op. 1, sp. 1186, k. 73v.

${ }^{20}$ ЦДІА, f. 201, op. 4б, sp. 1917, k. 315v, 317v-318, 319v; Візитацї̈ василіанських монастирів Перемишльскої епархї 1747-1767 років, wуd. Ю. Стецик, Жовква 2016, s. 98, 106, 112. 
tach. Zlokalizowane one były przy klasztorze oraz w Porubach i Borku ${ }^{21}$. Archimandria (opactwo) w Owruczu w 1750 r. posiadała trzy folwarki. Obok klasztornego, w którym pańszczyznę odrabiało 25 poddanych ze wsi i siedlisk: Łukiszki, Biłka, Telatycze, Kierdany, bazylianie dysponowali folwarkiem we wsi Litki (gdzie pracowało 21 poddanych ze wsi Litki, Ostapy, Radochoszcza) oraz kluczem szepelickim złożonym z kilku wsi (Nowe Szepelice, Stare Szepelice, Koszarówka, Bieniówka, Czystohołówka, Rudki, Dynysowicze, siedlisko Worochobowicze ze 129 poddany$\mathrm{mi})^{22}$. Z kolei monaster w Świętym Spasie posiadał dwa folwarki: świętospaski (22 poddanych) i w Busowiskach (47 poddanych) ${ }^{23}$. Podobnie do bazylianów w Podhorcach należały dwa folwarki: przy monasterze oraz we wsi Hałubica. W latach 60. XVIII w. przybył jeszcze jeden folwark, nazywany Buhajowskim, zlokalizowany w Podhorcach ${ }^{24}$. Monaster w Hoszczy w połowie XVIII w. obok jurydyki w pobliżu klasztoru posiadał folwark we wsi Kurozwany ${ }^{25}$.

Zdarzały się również sytuacje, że monastery posiadały tak mało gruntu, że nie organizowano formalnego folwarku. Tak było w Swaryczowie, dysponującym w 1775 r. polem ornym liczącym ok. 3/4 łana (ok. 18 ha). Pod monasterem osiedlono trzech poddanych, oddając im jedynie ogrody i grunt orny na dwa dni orania $(1,2 \mathrm{ha})^{26}$.

Tabela 1. Wielkość gruntów ornych oraz liczba poddanych w dobrach monasterów bazyliańskich w drugiej połowie XVIII w.

\begin{tabular}{|c|l|c|c|c|c|c|c|c|}
\hline \multirow{2}{*}{ Lp. } & \multirow{2}{*}{ Monaster } & \multicolumn{2}{|c|}{ Grunt orny } & \multicolumn{5}{|c|}{ Poddani } \\
\cline { 2 - 9 } & miara $^{27}$ & w ha $^{28}$ & $\begin{array}{c}\text { sprzę- } \\
\text { żajni }\end{array}$ & piesi & $\begin{array}{c}\text { czyn- } \\
\text { szowi }\end{array}$ & $\begin{array}{c}\text { zwol- } \\
\text { nieni }\end{array}$ & razem \\
\hline 1. & Bilcze & 1 lan & 24,2 & 10 & - & - & - & 10 \\
\hline 2. & Białołówka & 133 & 79 & 9 & 7 & - & - & 16 \\
\hline
\end{tabular}

${ }^{21}$ ЦДІА, f. 201, ор. 4б, sp. 1917, k. 268; Візитацї̈ василіанських монастирів..., s. 118.

22 Державний архів Тернопільської області (dalej: ДАТО), f. 258, op. 3, sp. 1254, Inwentarze monasterów bazyliańskich 1741-1772, k. 183v-190v.

${ }^{23}$ ЦДІА, f. 201, ор. 4б, sp. 1917, k. 334v-335; Візитацї василіанських монастирів..., s.159-163.

24 ДАТО, f. 258, op. 3, sp. 1254, k. 224, 225v; ЦДІА, f. 684, op. 1, sp. 2627, Inwentarz monasteru w Podhorcach 1767-1772, k. 7-7v.

${ }_{25}$ ДАТО, f. 258, op. 3, sp. 1254, k. 72-74.

${ }^{26}$ ЦДІА, f. 201, op. 4б, sp. 141, Inwentarz monasteru w Swaryczowie 1775-1787, k. 26,34 .

${ }^{27}$ Jeśli w tabeli nie zaznaczono jednostki powierzchni, to jest to dzień orania.

${ }^{28}$ Dla porównania obszaru gruntów rolnych należących do monasterów przyjęto, że dzień orania równał się 0,6 ha, a łan ziemi ok. 24,2 ha (łan frankoński). 


\begin{tabular}{|c|c|c|c|c|c|c|c|c|}
\hline 3. & Czernilawa & 50 pługów & 30 & \multicolumn{2}{|l|}{5} & - & - & 5 \\
\hline 4. & Czortków & 315 & 189 & - & 31 & - & - & 31 \\
\hline 5. & \begin{tabular}{|l|}
$\begin{array}{l}\text { Horodyszcze } \\
\text { (woj. wołyńskie) }\end{array}$ \\
\end{tabular} & 3 łany & 72,6 & 8 & 4 & 1 & - & 13 \\
\hline 6. & Jamnica (Smolin) & 65 & 39 & 11 & 3 & - & - & 14 \\
\hline 7. & Kołodeżna & 90 & 54 & \multicolumn{2}{|l|}{10} & - & - & 10 \\
\hline 8. & Krechów & 184 & 110,4 & 9 & 5 & - & - & 14 \\
\hline 9. & Litwinów & 50 & 30 & - & 6 & - & - & 6 \\
\hline 10. & Łuka & 30 & 18 & - & 2 & - & - & 2 \\
\hline 11. & Milcza Mała & 90 & 54 & 10 & - & - & - & 10 \\
\hline 12. & Ohladów & 3 & 1,8 & - & 4 & - & - & 4 \\
\hline 13. & Pitrycz & 39 & 23 & 4 & - & - & - & 4 \\
\hline 14. & Poczajów & $1271 / 2$ & 76 & 4 & 23 & 35 & - & 62 \\
\hline 15. & Satanów & 150 & 90 & 8 & 16 & - & - & 24 \\
\hline 16. & Sokulec & 42 & 25 & 6 & 5 & - & - & 11 \\
\hline 17. & Trembowla & 230 & 138 & 11 & 8 & 10 & - & 29 \\
\hline 18. & Uhorniki & 177 & 106 & 7 & 23 & - & - & 30 \\
\hline 19. & Ułaszkowce & 86 & 51 & 9 & - & - & - & 9 \\
\hline 20. & Uniów & 24 łany & 580,8 & 69 & 56 & 5 & 8 & 138 \\
\hline 21. & Wicyń & 48 & 28,8 & \multicolumn{2}{|l|}{4} & 1 & - & 5 \\
\hline 22. & Zawałów & 43 & 25 & \multicolumn{2}{|l|}{5} & 1 & - & 6 \\
\hline 23. & Zimno & 3 łany & 72,6 & 9 & 7 & 1 & - & 17 \\
\hline
\end{tabular}

Źródło: ДАТО, f. 258, ор. 3, sp. 1254, k. 22v-23, 102, 142, 151v, 225-225v, 245; ЏДІА, f. 201, ор. 4б, sp. 1917 , k. 479, 512-512v, 519v, 563-563v; ЦДІА, f. 684, op. 1, sp. 2029, Inwentarz monasteru w Krechowie, 1772 r., s. 79, 82; ІРНБУ, f. 231, nr 152, k. 206; Н. Теодоровичъ, Къ исторіи Колодежненскаго Вознесенскаго монастыря никогда существовавшаго въ Новоградъ-Вольнсколь уиздъ Вольнской губерніu, „Волынскія Епархіальныя Видомости” 1895, nr 22, s. 738; B. Lorens, Redukcja monasterów $w$ prowincji koronnej Zakonu Ruskiego św. Bazylego Wielkiego w latach 1744-1780, „Hereditas Monasteriorum" 8, 2016, s. 131-132.

Zaprezentowane w tabeli 1 dane świadczą o znacznej rozpiętości areału gruntów ornych w majątkach klasztorów bazyliańskich w południowo-wschodniej Rzeczypospolitej. Przeważały zdecydowanie klasztory posiadajace dobra ziemskie o powierzchni do 100 ha. Wśród nich wiele monasterów dysponowało gruntami porównywalnymi z gospodarstwem parochialnym (ok. 20 ha) ${ }^{29}$. Ośrodki monastyczne uposażone tak jak archimandria w Uniowie należały do wyjątków. O dużej

${ }_{29}$ T. Śliwa, Przemyska diecezja greckokatolicka $w$ XVIII w. (do 1772 r.), w: Polska - Ukraina. 1000 lat sasiedztwa, t. 3: Studia z dziejów greckokatolickiej diecezji przemyskiej, red. S. Stępień, Przemyśl 1996, s. 89; J. Półćwiartek, Parafie greckokatolickie diecezje przemyskiej $w$ XVIII wieku. Stan organizacyjny, pozycja gospodarcza $i$ społeczna, w: tamże, s. 96-97; A. Kołbuk, W. Kołbuk, Życie codzienne na probostwie unickim na ziemiach nadbużańskich w XVIII $i$ XIX wieku, Lublin 2015, s. 98. 
rozpiętości potencjału ekonomicznego majątków bazyliańskich świadczyły również dane związane z liczbą poddanych osiadłych na gruntach należących do monasterów. Zdarzały się przypadki, że poddani klasztorni osadzani byli bez przydzielenia im gruntu. Płacili wówczas czynsz z domostwa i trudnili się pracami zarobkowymi przy przedsięwzięciach budowlanych prowadzonych przez bazylianów. Taka sytuacja miała miejsce w latach 70. XVIII w. w Poczajowie, gdy budowano cerkiew Zaśnięcia $\mathrm{NMP}^{30}$.

Osadzajac poddanych w swych dobrach, bazylianie dążyli do rozdzielenia gruntu $\mathrm{w}$ oparciu o jednakowa miarę. W przypadku monasterów w Werchracie i Jamnicy chłopom wydzielano ziemię o wielkości 8 dni orania. Według przytoczonej w aneksie instrukcji do odmierzania gruntu służył sznur o długości 50 sążni, a więc prawie $90 \mathrm{~m}$. Pozwala to ustalić, że dzień orania wynosił 0,8 ha, co stanowiło nieco więcej niż przelicznik stosowany w Rzeczypospolitej ${ }^{31}$. Chłopi otrzymywali zatem 6,4 ha gruntu ornego. W zamian mieli płacić 6 złp rocznie. Do obliczania wymiaru pańszczyzny i danin nie brano pod uwagę ogrodów. Było to ustępstwem niestosowanym, jak zauważano, wobec chłopów w majątkach szlacheckich. Obowiazywała zasada nieobciążania poddanych nadmiernie, tak aby być konkurencyjnym w stosunku do sąsiednich dóbr. Wyartykułowane w instrukcji wezwanie do „dyskretnego i miłosiernego postępowania" w tym zakresie było dość często spotykane w wytycznych powizytacyjnych ${ }^{32}$. Pokrywało się także z zaleceniami stosowanymi w instruktarzach szlacheckich ${ }^{33}$.

Zarządzanie folwarkiem monasterskim i nadzorowanie poddanych polecano zakonnikom pełniącym funkcję prokuratorów. Niekiedy pomoca prokuratorom służyli bracia ekonomowie. Funkcje prokuratorów powierzano najczęściej osobom obeznanym z gospodarstwem ${ }^{34}$. Często pełnili ją przez całe swe zakonne życie, przenosząc się tylko z klasztoru do klasztoru ${ }^{35}$.

${ }^{30}$ IPНБУ, f. 231, nr 152, k. 206.

${ }^{31}$ A.W. Serczyk, Gospodarstwo magnackie $w$ województwie podolskim $w$ drugiej połowie XVIII wieku, Wrocław-Warszawa-Kraków 1965, s. 64; I. Wodzianowska, dz. cyt., s. 666.

${ }_{32}$ ЦДІА, f. 201, op. 4б, sp. 1917, k. 226; ЛННБ, f. 3, od. zb.293, k. 42v; ІРНБУ, f. I, nr 1104, k. 26v; IPНБУ, f. 231, nr 152, k. 171.

${ }^{33}$ Polskie instruktarze ekonomiczne..., t. 1, s. 45-47.

${ }^{34}$ Niektórych zakonników określano jako „zdatnych do prokuratorstwa”, „do gospodarstwa sposobnych”, „prokurator dobry”; zob. Archiwum Polskiej Prowincji Dominikanów w Krakowie (dalej: APPD), Ławra Poczajowska, sygn. 2, Skrutenia, k. 24v, 25, 27, 29v, 34, 49, 64, 66v, 109.

35 ЛННБ, f. 3, od. zb. 435, Cathalogus Alphabeticus..., t. 2, k. 116, 148, 149v, 150v, 155v; ЛННБ, f. 3, od. zb. 436, Cathalogus Alphabeticus..., t. 3, k. 131. 
W większości przypadków z racji bliskości folwarków prokuratorzy przebywali wraz z innymi braćmi w klasztorze. Zdarzały się jednak sytuacje, gdy folwark był znacznie oddalony od monasteru. Wówczas prokurator, często z towarzyszacym mu drugim zakonnikiem, przebywali stale w zabudowaniach folwarcznych, wśród których siłą rzeczy musiała być cerkiew lub kaplica. Dłuższe przebywanie poza konwentem nie sprzyjało realizowaniu obowiązków nakazanych reguła zakonną oraz zachowaniu klauzury. Pojawiały się oskarżenia prokuratorów o pijaństwo i gorszące kłótnie z czeladzią folwarczna. Z $\mathrm{Z}$ tego powodu unicki biskup łucki Teodozy Lubieniecki Rudnicki już w 1738 r. podczas wizytacji archimandrii w Mielcach na Wołyniu nakazał tamtejszym zakonnikom: „Zwyczaj na tym miejscu z niebezpieczeństwem i ujmą zakonności zsyłania osób zakonnych do folwarku dla dozoru, dotąd praktykowany, cale abrogujemy i dlatego podstarościego odtąd przy folwarku trzymać decydujemy"36. Jednak to rozwiazanie ze względu na konieczność zatrudniania osób świeckich i ich utrzymania było bardzo rzadko stosowane. Częściej bazylianie wydzierżawiali odległe folwarki w zamian za roczny czynsz. Bazylianie z Hoszczy wydzierżawiali swój majątek we wsi Kurozwany, za który otrzymywali 2100 złp rocznie ${ }^{37}$. Podobnie postępowali bazylianie z Szarogrodu, którzy w latach 70. XVIII w. wydzierżawili folwark w Kalinówce Antoniemu Dybkowskiemu ${ }^{38}$.

Najczęściej jednak folwarkami położonymi w bezpośrednim sasiedztwie monasteru zarządzali prokuratorzy zakonni. Nie byli w swych decyzjach samodzielni, lecz podlegali władzy przełożonego miejsca (ihumena, superiora), którego musieli informować o stanie gospodarstwa i pojawiajacych się $\mathrm{w}$ nim problemach. Zapewne $\mathrm{z}$ racji niewielkich odległości między klasztorem a folwarkiem informacje takie składane były ustnie i również tą drogą przekazywano polecenia. Dlatego w źródłach nie zachowały się wytyczne dawane prokuratorom co do postępowania w konkretnych sytuacjach. Tylko w przypadku rezydowania prokuratora w folwarku oddalonym od klasztoru na większą odległość występowała konieczność listownego porozumiewania się. Takim przykładem może być korespondencja między Benignusem Hościsławskim (Hościłowskim), prokuratorem folwarku w Woszczatynie, należącym do monasteru w Zahorowie na Wołyniu, a Gedeonem Lesiewiczem, ihumenem tegoż monasteru, pochodząca z $1766 \mathrm{r}^{39}$

${ }^{36}$ APPD, Ławra Poczajowska, sygn. 18, Inwentarz archimandrii w Mielcach, k. 12.

37 ЦДІА, f. 201, op. 4б, sp. 1917, k. 114v.

38 ІРНБУ, f. 231, nr 152, k. 180-181v.

${ }^{39}$ Fragmenty listów przechowywanych w Centralnym Państwowym Archiwum Historycznym Ukrainy w Kijowie (f. 2070, op. 2, spr. 41) opublikował diakon Bohdan 
Przywołana w aneksie instrukcja obowiąująca prokuratorów bazyliańskich nie była dokumentem obszernym w porównaniu do tego typu dokumentów dla urzędników dóbr magnackich czy szlacheckich. Liczyła 18 punktów, nierozdzielonych na części. Treść poszczególnych artykułów była zawarta najczęściej w jednym zdaniu, a maksymalnie w czterozdaniowej formie.

Według instrukcji zadaniem zakonnika obarczonego obowiązkami prokuratora było czuwanie nad sprawnym funkcjonowaniem folwarku i spokojnym życiem poddanych chłopów oraz służby folwarcznej. Do prokuratora należało podejmowanie działań w celu ukarania łamiacych obowiazujace zasady. Warto jednak zauważyć, że władze zakonne stały na stanowisku zachowania rozsądku w egzekwowaniu kar i oddziaływania bardziej słowem niż siła. Z praktyki stosowanej wobec poddanych w folwarkach Horodyszcze i Wołświn, podporządkowanych pod koniec lat 60. XVIII w. monasterowi w Krystynopolu, wynika, że wobec poddanych stosowano kary bardziej honorowe niż fizyczne, np. klęczenie i leżenie w cerkwi podczas nabożeństwa ${ }^{40}$. Prokuratorowi pozwalano na wymierzanie poddanym maksymalnie do pięciu plag, co również wydaje się być karą znacznie łagodniejszą w porównaniu z wielkościami w instruktarzach dotyczących dóbr szlacheckich ${ }^{41}$. Zadaniem prokuratora było pilnowanie, aby granice jurysdykcji klasztornej były oznaczone i nienaruszane. W przypadku stwierdzenia strat klasztoru miał zawiadomić przełożonego (ihumena) monasteru. $\mathrm{Z}$ drugiej strony zobowiązywano go do zachowania dobrych relacji z sasiadami i unikania konfliktów z nimi.

Prokurator czuwał nad wypełnianiem powinności poddańczych przez chłopów. Należała do nich głównie pańszczyzna, rozdzielana na letnia i zimowa. Jej terminy określano za pomocą kalendarza juliańskiego.

Pietnoczko na stronie internetowej bazylianów http://www.bazylianie.pl/index. php?option $=$ com_content\&view $=$ article\&id=1907:prokurator-ekonom-z-historii-bazyl iaskich-urzdow\&catid=16\&Itemid=3(9XI2017);zob.teżI. Wodzianowska,dz.cyt., s.667.

${ }^{40}$ Biblioteka OO. Bazylianów w Warszawie, sygn. Krystynopol 57, Księga gospodarska monasteru krystynopolskiego WW. OO. Misjonarzów Zakonu św. Bazylego Wielkiego oraz przyłączonych do niego dawnych tegoż zakonu monasterków Wołświńskiego i Horodyskiego R. P. 1767 sporządzona, k. 44.

${ }^{41} \mathrm{~W}$ instruktarzu z 1771 r. dla klucza zdzięcielskiego, położonego na Litwie $\mathrm{w}$ powiecie słonimskim, pozwalano wymierzyć poddanym (mężczyznom) nawet do 30 plag, a w dobrach Sarya w powiecie drysieńskim, należących w 1781 r. do Tomasza Łopacińskiego, do 10 plag; zob. Polskie instruktarze ekonomiczne..., t. 1, s. 108, 232. „Kilkanaście plag” dopuszczał instruktarz dany ekonomowi Aleksandrowi Krasnopolskiemu ze wsi Tatarynówka z 1794 r.; zob. ЛННБ, f. 141, op. 1, od. zb. 1482, Instruktarz dla ekonoma A. Krasnopolskiego, 1794 r., k. 3. 
Zwykle poddani ze sprzężajem odrabiali 2-3 dni w tygodniu w porze letniej oraz 1-2 dni w zimowej. Z kolei pańszczyznę piesza odrabiano 1-2 dni w porze letniej i 1 dzień w tygodniu w zimowej. W drugiej połowie XVIII w. bazylianie stosowali również zamiast pańszczyzny rentę pieniężną (czynsze). Poddani klasztorni zobowiązani byli do innych świadczeń na rzecz folwarków monasterskich: tłok i dni powabnych, stróży, szarwarków, kądzieli, itp. ${ }^{42}$ Egzekwowanie obowiązków pańszczyźnianych sprawiało bazylianom trudności. W 1763 r. w klasztorze w Dereżycach w ziemi przemyskiej skarżono się, że poddani, od dawna „krnąbrni” i „uparci”, „,z bida po jednym dniu przez cały rok na tydzień pańszczyznę odbywają" ${ }^{43}$. W gestii prokuratora było wyznaczanie odbywania dni pańszczyzny i pilnowanie, aby rozpoczynała się ona w lecie od godziny 7 rano. Jego zadaniem było również egzekwowanie wykonania określonych norm w ciagu dnia pracy. Wymóg punktualnego stawiania się w polu w dni odrabiania pańszczyzny pojawiał się również w innych zaleceniach wizytatorów bazyliańskich. Długość i trud pracy w letnie dni łagodzono poprzez wprowadzanie dwugodzinnej przerwy w południe ze względu na konieczność odpoczynku ludzi i zwierząt sprzężajnych. Takie rozwiazzanie zaproponowano w 1771 r., w wyniku skarg poddanych klasztoru w Milczy Małej. Skarżyli się oni, że dozorujaccy „wytchnąć nie dają. Ich zażalenie złożone przed odwiedzającym klasztor wizytatorem reprezentującym prowincjała zostało przyjęte ${ }^{44}$.

Protoihumen Jozafat Siedlecki przewidywał możliwość skarżenia się przez poddanych monasterskich na podwyższanie obowiązujących wymiarów posług i danin. Instancją do której zanoszono skargi, był ihumen monasteru. W przypadku gdy nie reagował on na zażalenie należało przedstawić je prowincjałowi podczas jego obecności w okolicy. Zakonnikom nie wolno było karać skarżących się chłopów. Takie prawo otrzymali poddani bazyliańscy w Wołświnie i Horodyszczu w 1765 r. ${ }^{45}$ Postanowienia te powtórzono, gdy oba monastery podporządkowano jako rezydencje klasztorowi w Krystynopolu ${ }^{46}$.

Porównanie obowiązków pańszczyźnianych i danin uiszczanych przez poddanych monasterskich $\mathrm{z}$ majątkami szlacheckimi oraz stosunkowo

${ }^{42}$ ЦДІА, f. 684, op. 1, sp. 1186, k. 72v-73; B. Lorens, Bazylianie prowincji koronnej..., s. 204-208.

${ }^{43}$ ЦДІА, f. 201, op. 4б, sp. 1917, k. 77v.

${ }_{44}$ ДАТО, f. 258, op. 3, sp. 1254, k. 176v-177; APPD, Ławra Poczajowska, sygn. 8, Inwentarz monasteru w Milczy Małej, 1787 r., k. 49v.

${ }^{45}$ ЦДІА, f. 201, op. 4б, sp. 1917, k. 212v.

${ }^{46}$ ЦДІА, f. 684, op. 1, sp. 3076, Inwentarz monasteru w Krystynopolu i filii w Wołświnie i Horodyszczu 1774, k. 98v. 
rzadko pojawiające się w dokumentach bazyliańskich skargi chłopskie prowadza do wniosku o mniejszych wymaganiach stawianych poddanym w folwarkach klasztornych. Świadczyła o tym m.in. sytuacja odnotowana w monasterze w Zbarażu w 1765 r., kiedy to superior Modest Śliwiński zaproponował zmianę dotychczasowych warunków egzekwowania pańszczyzny i podwyższenie wymiaru naturaliów, chcąc dostosować je do obowiązującej w sąsiednich dobrach, należących do starosty leżajskiego Józefa Potockiego ${ }^{47}$. Jego działania w tym względzie mogły być spowodowane oskarżeniami ze strony urzędników zarządzających dobrami Potockiego, że bazylianie postępuja ze swymi poddanymi zbyt pobłażliwie, pozwalając im na więcej niż było to w zwyczaju w dobrach szlacheckich $^{48}$. Decyzja o zmianie świadczeń musiała jednak zyskać akceptację ze strony władz prowincji. Sprawę zbadał na miejscu przysłany przez prowincjała wizytator klasztoru zbaraskiego Hieronim Kaletyński, który zauważył, że poddani klasztorni „nie poczytali tego za wielką przykrość, gdyż widza, że taka powinność pańscy poddani odbywaja”. Chłopi złożyli jednak suplikę na piśmie, w której oświadczyli, że nie moga być pociagani do takich samych świadczeń jak poddani w dobrach Potockiego, bo nie użytkuja gruntów o takiej wielkości jak oni. Wizytator w imieniu ihumena odpowiedział im, że otrzymaja grunty o wielkości podobnej do poddanych pańskich, a o zwiększeniu wymiaru świadczeń ostatecznie zadecyduja władze prowincji ${ }^{49}$.

Tendencja podwyższania świadczeń pańszczyźnianych nie była jednak obca bazylianom. Zdarzały się również sytuacje skarżenia się na ponoszenie większych ciężarów niż „u sąsiedzkich świeckich panów”. Z taką sytuacja zetknał się wspomniany już wizytator Hieronim Kaletyński w klasztorze w Zahajcach Małych na Wołyniu w kwietniu 1771 r. Tamtejsi poddani klasztorni utyskiwali na wydłużony termin odbywania pańszczyzny letniej o przeszło miesiąc $\mathrm{w}$ stosunku do sąsiednich majątków. Wizytator uznał ten termin, wprowadzony niedawno, za „nowość niegodziwa”, a ponadto z obawy, aby poddani „na swobodę nie powlekli się", zalecił dostosować czas odrabiania pańszczyzny letniej do obowiazującego w sasiednich dobrach ${ }^{50}$.

${ }^{47}$ ЦДІА, f. 201, op. 4б, sp. 1917, k. 521v-522; В. Lorens, Bazylianie prowincji koronnej..., s. 208.

${ }_{48}$ ЛННБ, f. 5, op. 1, od. zb. 2074/II, Księga historyi monasteru zbaraskiego, 1762 r., k. 17. Taka opinia urzędników dworskich Potockiego została sformułowana przy okazji skarg składanych na poddanego klasztornego Pawła Mykytkę. Dworscy Potockiego mieli wówczas mówić ihumenowi klasztoru zbaraskiego: „Dajecie ojcowie rozpustę poddanym, nie umiecie rządzić onemi”.

${ }^{49}$ ЦДІА, f. 201, op. 4б, sp. 1917, k. 521v-522, 526v.

${ }^{50}$ IP НБУВ, f. 231, nr 152, k. 171. 
Bazylianie obawiali się zbiegostwa chłopów i przenoszenia się do innych majątków z bardziej korzystnymi warunkami osiedlenia się. Zjawisko to występowało szczególnie w latach 70. XVIII w. na terenie Podola. Odnotowano je w aktach klasztoru w Satanowie, gdzie zapisano kilkanaście przypadków ucieczek chłopskich spod jurysdykcji monasterskiej ${ }^{51}$. Zdarzenia te wywołały w końcu reakcję władz bazyliańskich, bo podczas wizytacji monasteru w Satanowie w 1785 r. prowincjał Jozafat Ochocki wobec zwiększania obciążeń ludności poddańczej nakazał: „Gdy klasztor tutejszy mało ma poddanych, a tych bardzo ubogich, przecież miejscu temu użytecznych, przeto zalecamy x. przełożonemu, aby na nich był względny, żadnemi nowościami onym się nie uprzykrzał, przestając na dawnym co do ich powinności i użytków zwyczaju" ${ }^{52}$. Z kolei prowincjał Józef Morgulec podczas wizytacji monasteru w Lubarze na Wołyniu w $1777 \mathrm{r}$. ze względu na obciążenia podatkowe wprowadził zakaz zwiększania powinności chłopskich nad to, co zapisano w inwentarzu sporządzonym na początku lat 60 . XVIII w. za prowincjalstwa Atanazego Szeptyckiego ${ }^{53}$. Wydaje się, że jego opinia odzwierciedlała stosunek bazylianów do poddanych. Dla zakonu i prowincji korzystniejszym okazywało się poprzestanie na świadczeniach ustalonych w poprzednich dziesięcioleciach niż straty spowodowane wychodźstwem lub zbiegostwem. Starano się również dostosować obciążenia ludności poddańczej do tych, które istniały w sasiednich majątkach lub też nawet nieco mniej wymagać, aby przez to pozyskać przychylność poddanych.

Instrukcja z 1768 r. zobowiązywała prokuratora do roztoczenia szczególnej opieki nad budynkami folwarcznymi, kontrolowania ich stanu i dokonywania koniecznych napraw. Zabudowania w zdecydowanej większości były bardzo skromne. Z opisów wizytacyjnych wyłania się obraz drewnianych budynków krytych słomą. Wśród zabudowań folwarcznych w najlepszym stanie były zwykle rezydencje przeznaczone dla zakonników, najczęściej prokuratora i parocha, obsługującego parochię. Przeważnie były to chałupy kryte gontem, złożone z dwóch cel z alkierzami. Komorę dla pracowników folwarcznych umieszczano często przy piekarni. W pobliżu lokalizowano stajnie „wołowa” i „konna”, obory, chlewy, wozownie, gumna, chruściane szopy ${ }^{54}$. Według opisu

${ }^{51}$ ЛННБ, f. 5, op. 1, od. zb. 2106/II, Księga historyk monasteru satanowskiego, 1770 r., k. 10, 18v, 29-29v; B. Lorens, Bazylianie prowincji koronnej..., s. 209-210.

${ }_{52}$ ЛННБ, f. 3, od. zb. 293, Liber actorum et gestorum Monasterij Satanoviensis, 1769 r., k. $42 \mathrm{v}$.

${ }^{53}$ IP НБУВ, f. I, nr 1104, k. 26v.

${ }^{54}$ ЦДІА, f. 684 , op. 1, sp. 2627, k. 7-7v; ЦДІА, f. 684, op. 1, sp. 3014, Inwentarz rezydencji w Topolnicy, 1768 r., k. 1; ДАТО, f. 258, op. 3, sp. 1254, k. 6v. 
wizytacyjnego monasteru w Werchracie z 1766 r. zabudowania folwarku były „częścią nowym parkanem, częścią starym ostrogiem obwiedzione”. Wśród nich znajdowały się „piekarnia z sienia i komora pod dachem słomianym”, „oborka z chlewkami”, „trzy stodółki rozłaczone, budowane z drzewa pod dachem słomianym" ${ }^{55}$. Jeszcze skromniej przedstawiały się zabudowania folwarczne w Jamnicy: dwie „dobre stodołki”, „obora na bydło dobra i chliwek ten cały dobrym płotem ogrodzony"56. Jako „porządne” określano w 1750 r. zabudowania folwarczne przy archimandrii w Owruczu ${ }^{57}$. Z kolei folwark monasteru w Podhorcach położony w tej wsi potrzebował „reparacji z gruntu”58. Podobna uwage zapisano w 1770 r. w odniesieniu do folwarku klasztoru w Milczy Małej. W tym folwarku nowe zabudowania wystawiono do 1780 r. ${ }^{59}$

Folwarki bazyliańskie to gospodarstwa rolno-hodowlane, a więc takie, w których były obecne oba składniki: produkcja rolna i hodowla zwierząt. Prokurator zarządzał pracami rolnymi (wysiew, zbiór i zwożenie zboża i siana), które miały być realizowane w odpowiednim czasie, jednak instrukcja - w przeciwieństwie do wielu wytycznych dotyczacych dóbr szlacheckich - nie precyzowała terminów robót. Prokuratora zobowiązano do osobistego doglądania pracy chłopów i prowadzenia dokładnego rejestru wysiewów i plonów.

Instrukcja wyznaczała zasady obowiązujace w hodowli. Zalecano dbanie o zwierzęta i przychówek, aby gospodarstwo nie ponosiło strat z winy nadzorującego. Poważnymi oskarżeniami pod adresem prokuratora były zarzuty, że „bydło w gnoju stać musi i pod niebem”60. Według instrukcji $\mathrm{w}$ folwarku stosowano tzw. pakt, a więc wydzierżawiano oborę i drób poddanym w zamian za opłatę $\mathrm{w}$ naturze lub pieniądzu. $\mathrm{W}$ ten sposób bazylianie unikali zatrudniania wielu pracowników, a przy okazji w folwarku zostawał obornik, stanowiący podstawę nawożenia ziemi. System dzierżawy obór był bardzo często stosowany w XVIII w. ${ }^{61}$ Instrukcja określała wymagania dotyczące opłat za drób „paktowy”. Przewidywała, że za jedną kurę należało rocznie oddać 2 kury, 1 kapłona i 15 jaj, za kaczkę 4 kaczki i 8 jaj, za gęś - 4 gęsi i 5 jaj, a za indyczkę - 3 indyki i 4 jaja.

${ }^{55}$ ЦДІА, f. 684 , op. 1, sp. 1186, k. 4v.

56 Tamże, k. 43v.

57 ДАТО, f. 258, op. 3, sp. 1254, k. 183v.

58 Tamże, k. 225.

59 „Wszystkie budowle znacznej reparacyi i poszycia potrzebuja”; APPD, Ławra Poczajowska, sygn. 8, k. 1.

${ }^{60}$ APPD, Ławra Poczajowska, sygn. 2, k. 24.

${ }^{61} \mathrm{~J}$. Topolski, Gospodarstwo wiejskie w dobrach arcybiskupstwa gnieźnieńskiego od XVI do XVIII wieku, Poznań 1958, s. 227, 234-235. 
Te liczby nie odbiegały znacząco od wielkości pobieranych w folwarkach szlacheckich ${ }^{62}$. Według wytycznych obowiązujących bazyliańskiego prokuratora od jednej krowy należało rocznie oddać 6 garncy masła i 12 garncy (kopę) sera. Były to również wielkości stosowane w tym samym czasie w folwarkach szlacheckich ${ }^{63}$. Taką samą ilość masła i sera jak od jednej krowy należało odebrać od czterech owiec ${ }^{64}$. Powyższy system dzierżawy inwentarza żywego nie był stosowany we wszystkich folwarkach bazyliańskich. Z inwentarza folwarku klasztoru w Milczy Małej, obejmujacego lata 1773-1775, wynika, że nie było tam „paktu”. W celu przeliczenia dochodów i wydatków stosowano jednak następujący przelicznik: od jednej gęsi - dwie sztuki, od kaczki i kury - po trzy sztuki ${ }^{65}$.

Do pomocy w gospodarstwie folwarcznym zatrudniano najczęściej od 3 do 5 osób. Wśród nich byli: gospodarz, gospodyni, parobkowie, pastuchowie i dziewczęta do pomocy gospodyni. Ich obowiązki przewidywały np. dozór budynków gospodarczych, wypas i doglądanie inwentarza żywego, ogłaszanie pańszczyzny, pieczenie chleba i pranie ${ }^{66}$. Zadaniem prokuratora było ich wynagradzanie. Zapłatę wypłacano w pieniądzu i naturze. W Milczy Małej w 1773 r. prokurator płacił gospodyni, parobkom i pastuchom po 100 złp rocznie, a świniarzowi i poganiaczom po $50 \mathrm{złp}^{67}$. W folwarku kurozwańskim należaccym do monasteru w Hoszczy bazylianie zatrudniali „wójta do rozkazowania na pańszczyznę, któremu raz na rok wydawano odzież (siermięgę, czapkę, chusty) i buty ${ }^{68}$.

\section{Uwagi końcowe}

Bazylianie jako właściciele dóbr klasztornych musieli podejmować działania związane z ich organizacją i zarządem. Nie zawsze mieli

${ }^{62}$ Polskie instruktarze ekonomiczne..., t. 1, s. 97. Np. w dobrach wielaszkowickich na Litwie od jednej kury oddawano 2 kury, 1 kapłona i 20 jaj, od gęsi - 3 gęsi i 6 jaj, od kaczki - 3 kaczki i 20 jaj, od indyczki - 2 indyki i 6 jaj. Podobnie w dobrach Buczemla i Oleszkowice w latach 1757-1759: od gęsi - 3 gęsi i 1 jajo, od kury - 4 kury, 1 kapłon, 10 jaj, od kaczki - 4 kaczki; zob. Instrukcje gospodarcze dla dóbr magnackich $i$ szlacheckich..., t. 1, s. 488.

${ }^{63}$ Polskie instruktarze ekonomiczne..., t. 1, s. 74; Instrukcje gospodarcze dla dóbr magnackich $i$ szlacheckich..., t. 1, s. 439, 488, 505.

${ }_{64} \mathrm{Z}$ kolei w folwarkach szlacheckich kopę sera i 5 garncy masła uzyskiwano od 12 owiec; zob. Instrukcje gospodarcze dla dóbr magnackich $i$ szlacheckich..., t. 1, s. 105.

${ }^{65}$ IP НБУВ, f. 231, nr 152, k. 189v.

${ }^{66}$ Biblioteka OO. Bazylianów w Warszawie, sygn. Krystynopol 57, k. 3v-5v; ЦДІА, f. 684, op. 1, sp. 2044, Inwentarz monasteru w Krechowie, 1759 r., k. 15v.

${ }^{67}$ ІР НБУВ, f. 231, nr 152, k. 195.

68 ДАТО, f. 258, op. 3, sp. 1254, k.75v. 
ku temu dobre warunki. Ze względu na skromne warunki materialne monasterów nie zatrudniali zarządców czy ekonomów, ale samodzielnie zarządzali folwarkami małymi i zlokalizowanymi w pobliżu klasztoru. W przypadku większych kluczy dóbr, położonych w pewnej odległości od klasztoru, wydzierżawiali je szlachcie w zamian za roczny czynsz. Pochodzenie i doświadczenie życiowe prokuratorów bazyliańskich, wywodzących się często z rodzin duchowieństwa unickiego, mieszczaństwa czy ubogiej szlachty, nie odróżniało ich od stylu życia poddanych. Mogło to wpływać na wzajemne zbliżenie, ale nie podnosiło prestiżu i powagi zakonników jako nadzorujących funkcjonowanie folwarku. W działalności rolno-hodowlanej bazylianie wzorowali się na gospodarce stosowanej powszechnie w XVIII w. Nie byli innowatorami w tym zakresie, lecz raczej dostosowywali się do warunków panujących w okolicznych majątkach. Uposażenie w grunty orne oraz ilość chłopów zobowiązanych do świadczeń pańszczyźnianych w folwarkach bazyliańskich świadczyły o niewielkich możliwościach produkcyjnych tych majątków. Chcąc zatrzymać poddanych, starano się zapewniać im korzystniejsze warunki niż w dobrach szlacheckich. Chłopi mogli zgłaszać skargi do przełożonego klasztoru i prowincjała lub jego reprezentanta, a wysokość świadczeń gruntowych wymagała akceptacji władz prowincji. Z drugiej strony zależność od magnackich i szlacheckich fundatorów sprawiała, że bazylianie musieli liczyć się z ich opinią również w kwestiach gospodarowania we własnych dobrach.

\section{Aneks}

Materiał źródłowy pochodzi z inwentarza monasteru w Werchracie i rezydencji w Jamnicy, zawierającego wpisy z lat 1766-1775, przechowywanego w Centralnym Państwowym Archiwum Historycznym Ukrainy we Lwowie (Центральний Державний Історичний Архів України м. Львів), w zespole (fondzie) 684 - Protoihumenat klasztorów Zakonu św. Bazylego Wielkiego we Lwowie (Протоігуменат монастирів Чину св. Василія Великого, м. Львів), ор. 1, sp. 1186 Inwentarz monasteru w Werchracie z rezydencją w Jamnicy 1766-1775, k. 71-72.

W wydaniu posługiwano się zasadami wskazanymi w instrukcji wydawniczej opracowanej pod redakcja Kazimierza Lepszego ${ }^{69}$ oraz

${ }^{69} \mathrm{~K}$. Lepszy, Instrukcja wydawnicza dla źródeł historycznych od XVI do połowy XIX wieku, Wrocław 1953. 
uwagami sformułowanymi przez Jerzego Dygdałę ${ }^{70}$. Starano się uczynić tekst zrozumiałym, ale z drugiej strony zachować koloryt językowy. Interpunkcję oraz pisownię wielkimi i małymi literami uwspółcześniono. W nawiasie kwadratowym umieszczono numery kart. Nawias ostrokątny zastosowano w rozwiązaniach skrótów.

I. [k. 71] Informacja, jak wydzielać pole

Aby poddaństwo bez krzywdy, albo jeden nadto, drugi mniej grontu nie trzymał, zostawało, i zarównie wszystkim było, wydzielać onym pole trzeba sznurem wymierzonym z gromadzkiego, w którym być powinno sążni 50, a łokci ryńskich dobrych 150 . Takim tedy sznurem każdemu poddanemu ciąłemu, prócz ogrodu, lubo dwór świecki do wymiaru i to inkluduje, wymierzyć należy sznurów dwa poprzek, a cztery wzdłuż, co uczyni poprzek sążni 100 dobrych, a wzdłuż sążni 200. Łokci zaś poprzek 300, a wzdłuż 600 , z którego wymiaru pola do orania każdy mieć będzie zarówno dobrych dni 8 .

I lubo z takiego pola wydziału przez danin, podatków różnych i pańszczyzny znacznie do dworów świeckich ludzie opłacaja, my bardzo dyskretnie z swoim poddaństwem i miłosiernie postępując złotych $6 \mathrm{z}$ takiego gruntu niechaj daja.

Resztę zaś pola, gdyby się pozostało, na klasztor obrócić lub poddanego osadzić lub [k. 71v] według ceny najmować, kto by zechciał salva melioratione, approbatione vel cassatione $\mathrm{J}<$ aśnie $>\mathrm{X}<$ iędz $>$ a Prowincjała Dobrodzieja we wszystkich punktach i dyspozycjach. Sianożęci do dalszego czasu, a podobno na klasztor suspendować się będa.

Takim sznurem wydzielone pole mierząc raz wszerz, dwa razy wzdłuż, nazywa się staje, a te wielorakie bywaja.

Staje królewskie, w których sążni wszerz 79 wzdłuż 880

Staje polskie, w których sażni wszerz 28 wzdłuż 336

Staje łanowe, w których sążni wszerz 96 wzdłuż 96

Staje gromadzkie ordynaryjne, w których sążni wszerz 50 wzdłuż 100

II. [k. 71v]. Informacja gospodarska

$1^{\text {mo }}$. Jako wszystkie początki od chwały Pana Boga zaczynać się powinny, tak $\mathrm{J}<$ aśnie $>\mathrm{X}<\mathrm{iądz}>$ Prokurator pilno ma mieć baczność w folwarku i na jurysdykcyi pod dyspozycją sobie powierzonym, aby żadna (broń Boże) obraza Boska, złodziejstwo, hultajstwo nie działo się, za co karać nieodstępnie.

70 J. Dygdała, $Z$ doświadczeń edytora osiemnastowiecznych lustracji i inwentarzy - czy instrukcja wydawnicza jest w ogóle potrzebna?, w: Teoria i praktyka edycji nowożytnych źródeł $w$ Polsce (XVI-XVIII w.), red. A. Perłakowski, Kraków 2011, s. 143-158. 
$2^{\text {do }}$. Mieć wzgląd nie tylko na gospodarstwo folwarczne, ale i na poddaństwo, aby każdy z nich nie opuszczał się, dosiewając na zimę i na wiosnę.

$3^{\text {tio }}$. Ma pamiętać, aby bardziej rozsądnym hukiem a nie pukiem wykrocznych poprawował, a gdyby się obejść nie mogło pięć plag najwięcej pozwala się.

$4^{\text {to }}$. Uważnie tygodniowa pańszczyzna tylko w potrzebie dysponować, następujacca przed czasem nigdy, a zawodzić dla uprzykrzenia nie dopuszczać i nie marnotrawić.

$5^{\text {to }}$. Na granice wiedzieć, i one objeżdżać przestrzegajac, aby gronta nie były na stronę przywłaszczone. Z sąsiadami kłótni wystrzegać się, okazyi wszelakiej unikać, a gdy się obejść nie może, zwierzchności donieść. $6^{\text {to }}$. Budynki folwarczne i gruntowne, jako to gumno, obory, chlewy, stodoły, płoty, statki mieć na oku, a co się psuje wcześnie naprawować nieodwłocznie, aby przez opuszczenie i zaniedbanie do większej pracy i kosztów nie przyszło.

$7^{\mathrm{mo}}$. Co do polowego gospodarstwa, jako to do uprawienia roli, wczesnego ziarnem zasiania, sucho i w czasie zbóż i siana zbierania, zwożenia, składania, ukrywania, od szkody ubezpieczenia i dopilnowania, sama atencja, miłość dobra pospolitego szczera, sposobić się będzie.

$8^{\text {vo }}$. Przy zasiewach bywać i co się wysieje na każdym miejscu zapisywać do rachunku.

$9^{\text {no }}$. Zboża, gdy się zwozić będa, pierwej kopy obrachować, i adnotować. Toż się ma rozumieć o kopicach i o sianie.

$10^{\mathrm{mo}}$. Omłoty każdodzienne adnotować, słomy paszyste składać porządnie, aby nie ginęły ku dalszej potrzebie i miarę mieć sprawiedliwą.

$11^{\text {mo }}$. Ogrody zasiewać należycie, i konopi dosiewać najwięcej, z których włókno czyste mykanki, paczoski, kłaki odbierać, i jedne próbę z włókna, druga z mykanek, trzecią zgrzebną i worową uprzasść kazać, [k. 72] potym rozdawać do przędzenia. Połsetek snować arszynów 50, na który tyle motków, ile pasem snuje się wychodzić ma, arszyn zaś ani większy, ani mniejszy być nie powinien, tylko jak półmotowidła, a motowidło na ośm piędzi.

$12^{\mathrm{mo}}$. Bydła rogate i dobytki pilny dozór mieć powinny, aby nie kaleczały się, i bez przyczyny nie zdychały, najprzód, aby obory, i chlewy były porządne, suche, dobrze okryte, od wiatrów ochyszczone, wodą żeby nie podchodziły, słoma suchą podesłane, z jasłami, pod szopa i środkiem, ciasności jednak przestrzegając. Krowy na bliskim wycieleniu będące, aby od drugiego bydła nie były potrącane dozierać. Po wycieleniu zaś paszy onym dobierać i same cielęta wysysać one mają przez niedziel 
sześć. Po którym czasie od cycka cielę odłączyć, do paszy, obroku, siana, grysu i ziarna przyuczać, skrapiając ropa, wygodę czynić, inaczej gdyby zdechło z niedozoru zapłacić trzeba.

$13^{\text {to }}$. Obora chlewowa podobnego opatrzenia, wygody i dozoru potrzebuje, wiekopośne lub konsze lub trochę późniejsze wieprzki najlepiej konserwować do karmienia, którym gdy minie po trzy lata do karmnika sadzać, i gdy ukarmiony zabije się, podroby z niego być powinny. Głowa, pochrzebt, schaby, kapie, czyli łopatki, nóg 4, kiełbasy, polędwice, sadło, do którego pochrzebtowa bielizna wchodzić powinna, kapiów i połci zbytecznie nie obrzynać.

$14^{\text {to }}$. Drób paktowy dozoru podobnego i wygody potrzebuje, od którego drobiu przychówek i pożytek ma być takowy:

$1^{\text {mo }}$. Od kury $1<$ jednej> kur 2, kapłonów 2, jajec 15

$2^{\text {do }}$. Od kaczki $1<$ jednej> kaczek 4 , jajec 8

$3^{\text {tio }}$. Od indyczki $1<$ jednej> indyków 3 , jajec 4

$4^{\text {to }}$. Od gęsi $1<$ jednej> gęsi 4 , jajec 5

NB <nota bene> Gęsi dwa razy do rok na wiosnę i pod jesień podskubane być maja. Pierze od nich dla potrzeby chować.

$5^{\text {to }}$. Od krowy $1<$ jednej> dwunastogarcową faskę lub kopę syra i sześciogarcową faskę masła pożytkować należy.

$6^{\text {to }}$. Od czterech owiec tyleż masła i syra odebrać trzeba, które owce na wiosnę i pod jesień strzyżone bywaja, i dwie runa na pożytek do roku składaja.

$15^{\text {to }}$. Aby dobrze młócono pilnować należy, i grubsze poślady jako to zagoniny, tryny, kłosiny, szczebiny, i plewy na suchym miejscu maja być składane, aby się nie psuły ku potrzebie zimowej.

$16^{\text {to }}$. Na poszycie i pokrycie budynków słomę konserwować trzeba.

$17^{\mathrm{mo}}$. Czeladzi na zapłacenie i rzemieślnikom o perceptę starać się z przychówku, z obory, ogrodów i gumna, nie spuszczając się na kasę. $18^{\mathrm{vo}}$. Wzwyczaić, aby w lecie o siódmej godzinie na pańszczyznę przychodzono, kopę ozimego, a półtory kopy zboża jarego na dzień użęto, etc. więcej pilna industria informować będzie.

\section{Bibliografia}

\section{Źródła archiwalne}

Archiwum Polskiej Prowincji Dominikanów w Krakowie: Ławra Poczajowska, sygn. 2, 8, 18.

Biblioteka Jagiellońska w Krakowie: rkps 4502.

Biblioteka OO. Bazylianów w Warszawie: sygn. Krystynopol 57. 
Центральний Державний Історичний Архів України м. Львів: f. 201, ор. 4б, sp. 141, 1917; f. 684, op. 1, sp. 1186, 2029, 2044, 2627, 3014, 3075, 3076. Державний архів Тернопільської області: f. 258, op. 3, sp. 1254.

Львівська Національна Наукова Бібліотека України імені Василя Стефаника. Відділ Рукописів: f. 3, od. zb. 137, od. zb. 293, od. zb. 361, od. zb. 435, od. zb. 436; f. 5, op. 1, od. zb. 2074/II, od. zb. 2106/II; f. 141, op. 1 , od. zb. 1482.

Інститут Рукопису Національної Бібліотеки України ім. В. І. Вернадського в Кииіві: f. I, nr 1104; f. 231, nr 152.

\section{Źródła drukowane}

Instrukcje gospodarcze dla dóbr magnackich $i$ szlacheckich $z$ XVII-XVIII wieku, t. 1, wyd. B. Baranowski i in., Wrocław 1958 (Źródła do Historii Kultury Materialnej).

Instrukcje gospodarcze dla dóbr magnackich i szlacheckich $z$ XVII-XVIII wieku, t. 2, wyd. B. Baranowski i in., Wrocław-Warszawa-Kraków 1963 (Źródła do Historii Kultury Materialnej).

Polskie instruktarze ekonomiczne $z$ końca XVII i z XVIII wieku, t. 1-2, wyd. S. Pawlik, Kraków 1915-1929.

Візитацї̈ василіанських монастирів Перемишльскої єпархї̈ 1747-1767 років, wyd. Ю. Стецик, Жовква 2016.

\section{Opracowania}

Duch O., Jak mniszki gospodarowaty? Gospodarka w prawostawnych i unickich monasterach żeńskich eparchii lwowskiej i przemyskiej $w$ XVII-XVIII wieku, w: Folwark, wieś, latyfundium. Gospodarstwo wiejskie $w$ Rzeczypospolitej $w$ XVI-XVIII wieku, red. J. Muszyńska, S. Kazusek, J. Pielas, Kielce 2009, s. 187-196.

Kołbuk A., Kołbuk W., Życie codzienne na probostwie unickim na ziemiach nadbużanskich w XVIII i XIX wieku, Lublin 2015.

Lorens B., Bazylianie prowincji koronnej w latach 1743-1780, Rzeszów 2014.

Lorens B., Sytuacja gospodarcza monasterów bazylianskich w Galicji u progu kasat józefinskich oraz losy ich majatku po kasacie. Zarys problemu, $\mathrm{w}$ : Klasztor $w$ gospodarce średniowiecznej i nowożytnej, red. M. Derwich, Wrocław 2013 (Opera ad historiam monasticam spectantia, I, 9), s. 623-641.

Łoś W., Sytuacja gospodarcza klasztorów bazylianek na Wotyniu u progu kasat (koniec XVIII - poczatek XIX w.), w: Klasztor w gospodarce średniowiecznej $i$ nowożytnej, red. M. Derwich, Wrocław 2013 (Opera ad historiam monasticam spectantia, I, 9), s. 611-621.

Miławicki M., Zaplecze gospodarcze klasztorów dominikańskich diecezji kamienieckiej $w$ świetle akt wizytacji z 1823 roku, w: Dominikanie na ziemiach 
polskich w epoce nowożytnej, red. A. Markiewicz, M. Miławicki, Kraków 2009 (Studia i Źródła Dominikańskiego Instytutu Historycznego w Krakowie, 5), s. 485-517.

Rutkowski J., Co to byty folwarki w dawnej Polsce?, w: Wieś europejska późnego feudalizmu (XVI-XVIII w.), wybór J. Topolski, Warszawa 1986, s. 232-263.

Serczyk A.W., Gospodarstwo magnackie w województwie podolskim w drugiej połowie XVIII wieku, Wrocław-Warszawa-Kraków 1965.

Wodzianowska I., Sytuacja gospodarcza klasztoru bazylianów w Zahorowie na Wotyniu u progu kasat oraz losy jego majatku i zabudowań po kasacie $w 1839$ r., w: Klasztor $w$ gospodarce średniowiecznej i nowożytnej, red. M. Derwich, Wrocław 2013 (Opera ad historiam monasticam spectantia, I, 9), s. 663-682.

Стецик Ю., Монастирські фбільварки Перелишльської епархї̈ (кінець XVII-XVIII cm.), „Історія релігій в Україні” 1, 2008, s. 540-546.

\section{Beata Lorens}

Basilian Fathers as owners of the monastic estates in the second half of the eighteenth century

(Summary)

The Order of St Basil the Great (Ordo Sancti Basilii Magni), from the 1617 reform representing the Catholic monasticism of the Eastern rite, was the owner of landed estates, most often conferred to them under founding charters. Landed estates of the Basilian Fathers were organised in the form of manorial farmsteads cultivated to provide for their own needs. Usually, they were small farms up to one hundred hectares (often 20-40 ha), and a small number of subjected peasants (2-30 peasants). Larger manors, especially those that covered whole villages in a certain distance from the monastery, were leased to the nobility for a fixed annual pecuniary rent. The manors were administered by Basilians appointed to the post of procurator or stewards. They were given economic instructions containing rules of their conduct towards the monastery's subjects, and their duties as supervisors of the monastic farmsteads. An example of such document was the instruction of 1768 for the procurator of the manor at the village of Werchrata and the subservient residence at Jamnica, located in the Bełz Voivodeship. The instruction contains rules of the procurator's conduct towards the owners of neighbouring estates, the domestics, servants and subjects of the monastery, his care for manorial buildings and livestock, for harvest and crops. An analysis of the regulations allows us to conclude that the Basilian Fathers were aware of their own economic weakness in comparison with estates of the nobility, and that they understood both the need to adjust peasant burdens to their means and capabilities, and to keep the manorial farms in good condition. 
Beata Lorens - dr hab., prof. UR, pracuje w Zakładzie Historii Nowożytnej i Dziejów Kościoła w Instytucie Historii Uniwersytetu Rzeszowskiego. Główne kierunki zainteresowań badawczych: stosunki religijno-etniczne na pograniczu polsko-ukraińskim w okresie nowożytnym, dzieje bazylianów prowincji koronnej w XVIII w., historia oświaty. Autorka trzech książek oraz ponad 60 artykułów naukowych.

Beata Lorens - Dr. hab., assistant professor at the Modern History and History of the Church Unit of the Rzeszów University; her research interests mainly focus on religious-economic relations at the Polish-Ukrainian borderlands in the early modern period, the history of the Basilian Fathers of the Crown province in the $18^{\text {th }}$ century, the history of education. The author of three books and over 60 scholarly articles.

E-mail: blorens@poczta.fm. 